基 調 講 演

紙パルプ技術協会 理事長 池 田 健 郎

\title{
Keynote Address
}

\author{
Kenro Ikeda \\ President ; JAPAN TAPPI
}

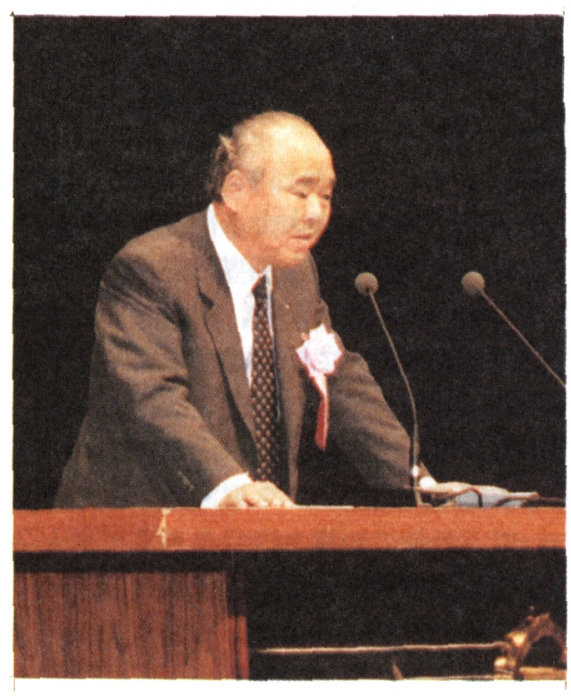

皆さん今日は, 平成元年度の年次大会を開催するに当たり

一言ご挨拶申し上げます。

本年は, この苫小牧市で開催致しましたところ, 約 700 名 の多数の方々のご参加をいただき，盛大に開会できましたこ とを非常に喜んでおります。年次大会は年々参加者が増加し て参り, 技術協会としましては, 今後とも皆様のご協力を得 まして, さらに大会の内容を充実させ会員相互の交流や技術 の向上，さらには国際的にも貢献できる年次大会にして行き たいと考えております。

本日は，東京大学 茅 陽一先生を招招きし，今日的話題 であります「地球規模の環境問題一21 世紀への選択」につき まして，また明日は白老民族文化伝承保存財団 伊藤裕満先 生に，「アイヌの郷土史一歴史と文化」について特別講演をお 願い致しております。さらに例年の如く，各関連の会社から の製品説明会も予定しておりますのでご活用戴きたいと思います。

さて, 恒例によりまして, 年次大会の冒頭に当たり，理事長として紙パルプ産業に関わる諸問題につき まして，日頃考えておりますことを申し上げてみたいと思います。

最初に取りあげたいテーマは「地球規模での資源・環境問題」でございます。

地球規模での資源・環境問題は, 紙パルプ産業と密接な関連がありますが, 茅先生に特別講演でお話を いただけますので，私は話題の提起程度にとどめさせていただきます。

近年，世界的に問題視されておりますものに，“フロンによるオゾン層の破壊”，“ $\mathrm{CO}_{2}$ などによる地球 の温暖化”, “ $\mathrm{NO}_{\mathrm{x}}$ や $\mathrm{SO}_{\mathrm{x}}$ などによる酸性雨問題”さらに“ダイオキシン関連物質”による環境污染など があります。

これらにつきましては, 対応可能な対策につきまして出来る限り早く実施に移して行かなければなら ないと考えております。

次に“産業社会の変化”に触れてみたいと思います。

近年，急速に変化しつつあります産業社会の変化について，そのインパクトを考えてみたいと思いま す。最初に「世界的変化」についてみてみますと世界は政治的にも経済的にも大きな変化の時代に入って 
おりまして，それにともなって産業社会も大きく変わろうとしております。その潮流は，“アメリカ基軸 の時代から主要国の協調時代”に移行しておりますし，“情報化時代の到来”が言われたり，人間の意識 が精神的・文化的な豊かさを重視する方向に変化しつつあるように思われます。さらに産業界では異分野 技術の融合化, 従来の産業の枠を越えた企業の多角化, すなわち「融業化ををもらし，産業構造にも変 化をもたらすとの見方が定着しつつあるのはご案内の通りであります。国際的には「自由化」「ボーダー レス」の方向で動いておりますので，これらへの対応力を養成しておくことが肝要と考えております。

次に「わが国の産業社会の変化」に触れてみたいと思います。

わが国の産業社会の変化は, 只今申し上げました世界的変化と同じような変化がみられます。ここでは 産業社会の変化とともに進展するソフト化 (サービス化), 情報化, 国際化について触れてみたいと思い ます。

まず “ソフト化 (サービス化)”の傾向ですが，産業のソフト化を就業構造の変化で見てますと第 3 次 産業, サービス産業の伸びが大きいと言う統計資料があります。さらに世の中のムードが 2 次産業の衰退 をあおっておりますし，大学新卒者の 2 次産業離れもこうした傾向の影響を受けているものと考えられ ます。そこで，これらの風潮を正常に戻さなければならないと考えております。

わが国のような資源・エネルギーに乏しい国では, 第 2 次産業の強化なしにわが国の経済発達はないと 考えておりますが，皆様いかがお考えでございましょうか。

次に“情報化”に触れますと, 高度情報化社会とはどんな社会か, 確たるものがないまま各人各様のイ メージが先行しているきらいがあります。アルビン・トフラーが「第三の波」で, 高度情報社会というまっ たく新しい文明形態が生まれつつあると説いて大反響を呼びましたことはご案内の通りでございます。

高度情報社会では情報やソフトウェアは, 重要な経営資源とみなされ, 企業の従来の経営資源でありま す「ひと・もの・金」に加えて情報が重要な資源となる時代であるといわれております。

高度情報社会が形成され, ニューメディアが実際に動きだした時, 産業界や人間の社会生活に大きなイ ンパクトを与えるものと思われます。

ニューメディアが社会に浸透した時, どういう影響が生じてくるか, まだ推測の域を出ませんが, 紙パ ルプ産業には情報化システムの利用と言う面とそれに使用される紙の供給との 2 つ面が考えられます ので，その動向を注視して行きたいと考えております。

最後に“国際化”について触れてみますと，わが国の紙パルプ産業の海外への投資活動は当初，原木資 源を確保する目的で展開され, 次いで原木資源やエネルギーや水が豊富で, かつ安価に入手可能な地域に 於いてパルプの現地生産が開始され, 製品の一定量を引き取る開発輸入型の投資が行われてきました。そ して, 最終製品である新聞用紙, 出版用紙へと進み，投資の形態も従来の現地企業との合併に加えて，現 地企業への資本参加, 既存工場の買収, さらには単独企業による工場建設と, その内容も幅広くなり, 紙 パルプ産業も本格的な国際化時代を迎えるに至ったと思われます。

これからの国際化戦略は産業の置かれた状況や, 各企業の経営戦略等によって当然異なってしかるべ きであります。したがって普遍性のある国際化戦略を産業レベルで論ずることはおのずと限界がありま すが, 国際化の必要性を一口で言えば「国際化することが目的ではなく，生き残り，成長していくために 国際化せざるを得ない」そうした時代を迎えようとしていると言うことでありましょう。

さて，次に「わが国の紙パルプ産業の現状と課題」に入りたいと思います。 
これにつきましては, “需給”, “企業業績”, “コスト競争力”, “原材料”, “エネルギー”, “品質対応と 新製品開発”, “研究開発”さらに“長期課題と展望”の 8 項目について触れてみたいと思います。

第 1 番の項目として “需給”を取り上げますと, 1988 年度の紙・板紙の需給は, 特に紙は第 1 次オイ ルショック以来の二桁の伸びとなりまして,ここ数年は特に好調であります。そのお院で各社とも最良の 決算を達成できましたことはご同慶の至りでございます。

紙の需要の好調な要因としましては個人消費, 設備投資を中心とする日本経済の内需拡大が挙げられ ます。特に個人消費の堅調は, 円高による物価の安定及び多様な海外製品の浸透と, 貿易摩擦を契機とし た輸出産業の内需掘り起こしが奏効したものと考えられます。

需要構造の変化としましては, 経済のソフト化・サービス化・情報化の流れが進み，これによって新聞 用紙を含めた印刷・情報用紙の需要にプラスし, 企業の広告・宣伝が活発化し, 印刷・情報用紙の需要拡 大に結びついたものと考えます。

一方, 設備投資の盛り上がりから産業活動が一段と活発となっていることをうけて, 産業資材包装用の 板紙の荷動きも好調でありまして良き年であったと言えましょう。

1989 年度の見通しにつきましては, 製紙連合会の試算によりますと, 紙の需要増は対前年 $6.9 \%$, 板紙 $4.4 \%$ ，合計で $5.9 \%$ との予測がありますが，その伸びの実現を期待したいものであります。

2 番目の項目であります“企業の業績”について触れますと, 紙パルプ産業の業績は, 紙系企業(印刷・ 情報用紙を主体とする企業）を中心に 1983 年度以降製造業の平均を上回る好決算を持続しております。 その収益増の要因を考えてみますと，第 1 の要因は紙・板紙の需要量の増大があげられます。

第 2 の，そして最大の収益増の要因は原材料費と燃料費の下落による変動費の低下であります。

第 3 の収益増要因は金利の低下，借入金の返済，資金調達の多様化による金融費用の減少であります。

以上, 収益増要因についてみましたが，1988 年度から今年にかけてチップ価格の上昇, さらには円安 傾向にありますので，従来と異なった視点からの施策が求められております。

3 番目の項目であります“コスト競争力”でありますが, 紙パルプ産業の場合, チップ, パルプ, 紙製 品ともに基本的には国際商品でありまして, 激烈な国際的競争場裡で生き残り, 安定的に成長を図って行 くためにはコスト競争力, 品質での差別化が必須であると考えます。

わが国のコスト競争力を左右する要因といたしましては, “為替レート”, “原材料 (チップ・重油)”の ウエイトが大きい変動費, さらに“生産性・人件費”のウエイトの高い固定費, それに“流通コスト”な どがありますが, われわれがコントロールすることが可能な要因につきましては, 競争力維持のための最 大限の努力をすべきと考えます。

4 番目の項目であります“原材料確保”について触れますと, わが国の紙パルプ産業が国際的競争の 中で生き残り, 安定的に成長して行くためには原材料が競合する海外メーカーとあまり不利にならない 条件で確保されることが重要であると考えます。

ここで “原木・チップ”についてみますと, 1988 年はパルプ生産の増加に伴いまして, パルプ材の消 費量も $7 \%$ という高率の伸びを示しました。このような消費量の大幅増加に対しまして, 供給面では国産 材が $2 \%$ 増に留まり一方, 外材は $17 \%$ と大幅な上昇となりまして, 外材入荷量, 外材依存率ともに史上 最高になったようであります。

外材の入荷に現れました特徵は, 一つには円高が寄与致しまして調達圈が輸送に 1 ヶ月強を要する南 米チリ一や輸送日数がアメリカ西部の約 2 倍もかかるアメリカ南部の遠距離地からの輸入が始まったこ 
とであります。将来の原木・チップの確保で，もう一つの重要なことは国産チップの安定供給でありま す。国産チップ安定供給を確保するためには, “若い労働者の確保”と“機械化による丸太・チップの生 産の労働生産性の向上などが急務であると考えております。

次に“古紙”でありますが，現在古紙は製紙用原料の約 5 割を占めるまでに高まってきておりますが, 地球規模の環境問題, 都市ゴミ問題を考えますと,一層の古紙利用の促進が今日的課題となってきている と考えております。

古紙の品種別需給をみてみますと, 新聞古紙や雑誌古紙, 段ボール古紙に関しましては回収・利用率も 高いレベルにありますので, 今後は残された分野, すなわち白物古紙, オフィスから出る古紙をうまく分 別して回収し，それを製紙原料として使用して行く可能性の追求が重要になってきていると考えます。い ま情報用紙は全体で約 120 万トン消費されておりますが，その中でコピー用紙と連続伝票用紙だけ合わ せても約 50 万トン位ありますので，この分野だけでも，ある程度回収できれば，原料の需給緩和につな がり意義あるものと思われます。

以上, 原材料関係をみてきましたが, 只今申し上げましたように多くの課題があります。そして一方で は高収率パルプや DIP を上質系に使用できるよう，製品規格の見直しを含めた検討の必要性も痛感して おります。

5 番目の“エネルギー”に移りますと，木材資源同様に，エネルギー資源にそしいわが国では，特にエ ネルギーを多消費する紙パルプ産業では省エネルギーの徹底, そのための合理化投資の必要性が要請さ れていると思います。

紙・板紙生産額に占める購入エネルギーのコスト比率は 1980 年の $20 \%$ 弱をピークに年々低下し, 1988 年には $10 \%$ 以下になってきております。

このようなエネルギーコスト比率の低下は “円高，原油安等によるエネルギー単価の低下”，及び“自 家発比率の向上，石炭への転換”，“省工ネ効果”，“古紙利用の促進”等が寄与したことによります。

ところが 1988 年は，購入エネルギー原単位の改善が 1976 年以来初めて足踏み状態となっております。 今年になってから原油価格は強含みに転じ, さらに最近の円安傾向は, エネルギー単価を上昇させており ますので一段の省エネルギーへの努力が要請されましょう。

6 番目の “品質対応と新製品開発”につきましては，資源・エネルギー源に乏しく，さらに公害規制の 厳しいわが国の紙パルプ産業が競争の激しい国際市場でコスト競争力の不利に耐え, 生き残り, 安定的に 成長を図って行くには，“品質対応と新製品開発”による製品の差別化が必須条件であると考えておりま す。

わが国の場合, 紙製品のみならず全ての製品に共通することですが, ユーザーからの品質要求が非常に 厳しく,このような環境下で生み出される高品質の製品が世界の市場で評価されて, 輸出が好調である反 面, 外国品が入り難くい最大の要因であることはご存知の通りであります。

紙の用途とユーザーからの品質要求は多様化・高度化してきておりますが, われわれはユーザーのニー ズを的確にとらえ, タイミング良く対応して行くことが肝要であります。最近のニーズ動向をみてみます と, 全般的な傾向として新聞・雑誌に加え, 複写機などでもカラー化がみられ，また注文量は少ロット多 品種化がみられます。

新製品開発についてみますと，紙の場合，外見上は一見従来と全く同じように見えますが，内容的には かなり改質されている場合が多々あります。これらを新製品と呼べるかどうか, その意味では紙分野では 全くの新製品と言うものは生まれにくい分野であります。ただ，この分野にもより特殊化・ファイン化， 新しい機能が付加された新製品開発がみられるようになりました。これが特殊紙・機能紙と呼ばれるもの 
であります。われわれの基本技術はシート化, 含浸, 塗工，ラミネートなどでありますが，さらに最適の 原材料を組合わせることにより新製品開発を進め，業界の安定成長の一助にしたいものであります。

7 番目には“研究開発”について触れてみます。

わが国の紙パルプ産業の研究開発の規模は（人員・金額とも）海外のパルプ・紙の主要生産国とほほ同 等でありますが, 他産業と此較すると低い水準にあります。

最近, 各企業とも研究開発の充害が図られておりまして, 喜ばしい限りでございますが, 今後とも経営 環境が許す範囲内で充実を図って行く必要性を感じております。

私自身, 長い間, 研究所におりましたが, 戦後の日本の研究所や技術者に求められていることを考えて みますと, 時代とともに変わってきているように思われます。すなわち, 技術導入でス夕ートしたわが国 の技術も，現在では世界のトップレベルにありまして，今後は自主技術の確立が要請されましょう。また 研究開発には独創性が要求されてきておりまして, 今後は量と質両面での充実を図って行かなければな らないと考える次第であります。

最後の項目であります “長期的課題と展望”に移りますと, 最近, 「21 世紀への挑戦」,「21 世紀へ向け ての中長期ビジョン・経営戦略」と言った言葉が多く見られます。これは 21 世紀を目前にして業界・企 業の基盤を強化しておこうとの熱意のあらわれと言えましょう。

紙パルプ産業との関連では, 紙パルプ技術予測研究会が “2010 年の紙パルプ・・21 世紀の紙パ戦略” をテーマに，需要・原材料・製品・技術の全般にわたるアンケートの集約結果を本年 4 月に発表されまし た。その内容は 20 年後を展望するのに示唆に富んだものであります。

また業界でも, 通産省生活産業局長の諮問機関として, “紙パルプ産業の長期課題に関する研究会”が 本年 9 月に発足いたしました。研究会の下に設けられた市場・企画部会, 原料部会のワーキンググループ で約 1 年にわたって研究されることになっており, その成果に期待が奇せられております。私共も一層の 研鑽を積み，長期的展望に立ち，21 世紀を目指した総合戦略を練り上げ，一層の飛躍への基盤強化を図 りたいものであります。

以上で, 私が考えておりますことの一端を申し述べましたが, 只今申しましたように, わが紙パルプ産 業は多くの課題をかかえておりますが, これらの難問の解消はわれわれ技術者の双肩にかかっていると 言っても過言ではありません。そのためには, 現状の課題と将来展望を正しくとらえ, 業界の問題はここ にお集まりの全員で, 企業の問題は各社の皆さんで, 創意工夫をこらし, 新しいアプローチで, 不退転の 決意で難題解消を図らなければならないと考える次第であります。まさに“千里の道も一歩より”であり ます。その一歩に，このような技術協会の行事を大いに活用されて，技術の向上に努めていただきたいと 考えます。協会と致しましても, 各種の企画を通じて会員の皆様の研鑽に役立つよう出来るかぎりの努力 を傾ける所存でございます。

本日は, 多数の方々のご参集を頂きまして，協会の役割の重要さを改めて認識した次第でございます。 最後になりましたが, 大会準備のために色々とお骨折り頂きました関係各位, 工場見学を始め,この年 次大会の間，終始お世話を頂きます王子製紙(侏)苫小牧工場の皆様方に厚くお礼を申し上げます。

ご静聴ありがとうございました。 


\title{
Keynote Address
}

\author{
Kenro Ikeda \\ President : JAPAN TAPPI
}

In opening the annual meeting for 1989 , I would first like to make a few general remarks.

This year, our meeting is being held in Tomakomai City with a successful turnout of about 700 participants. This is a source of great pride for us. Each year, the annual meeting has been attended by a greater number of participants. We of JAPAN TAPPI hope to gain your support and cooperation in coming years so that these mutual exchanges and discussions will continue to contribute to the advances of pulp and paper technology.

Today, we have invited Professor Yoichi Kaya of Tokyo University who will give a special lecture on a subject of topical interest_— "The Global Environmental Problem : Our Choices in the 21st Century." Tomorrow Hiromitsu Ito of the Shiraoi Ethnic Culture Folklore preservation Foundation will deliver a special lecture entitled "The Ainu Folk Chronicle: History and Culture." And as in past years, product briefing sessions also will be presented by related companies and we hope you will make full use of them.

As is customary at the outset of the annual meetings, as President of JAPAN TAPPI, I would now like to tell you some of my views on the problems relating to the pulp and paper industry.

First, I'd like to discuss The Global Resource and Environmental Problem.

The problem of resources and the environment has a close bearing on the pulp and paper industry and as Professor Kaya will give a special lecture on this subject, I will merely confine myself to introducing the topic.

In recent years, problems of worldwide proportion include the Destruction of the ozone layer by chlorofluorocarbon, the greenhouse effect caused by $\mathrm{CO}_{2}$ and other gases, and the problems of acid rain caused by NOx and SOx, and the environmental pollution caused by the Dioxin-related substances.

We in the pulp and paper industry must keep these problems in mind, and work to solve them as soon as possible.

Now, I world like to touch on some changes in industrial society.

Let's consider the impact of rapid changes that have been taking place recently in our industrial society. We can start with worldwide changes.

The world has entered into an era of great change both politically and economically. As a result, industrial society is about to undergo great transformation. The current is now shifting from the Americanbased era to the era of cooperation among major countries. This current is also referred to as the advent of the information era and I think that our race is moving in the direction of greater spiritual and cultural affluence.

In the World of industry, different technological fields are now being integrated, resulting in the trend towards integrated business through business diversification that goes beyond the conventional framework of industry. This, as you are aware, in the view that changes will also be brought about in industrial structure. Internationally, all this is evidenced in moves toward liberalization and borderless economies. I believe it is essential for us to be prepared for these changes.

Now, I would like to touch upon Changes in Japanese industry today.

Japanese industrial society is undergoing changes similar to the worldwide changes that I have just pointed out. Here, I would like to touch upon the growing emphasis on services, and the new internationalization which are taking place along with changes in industrial society. 
First, about the new emphasis on services.

Changes in employment structure are especially pronounced in tertiary or service industries. The present social mood is spurring a decline of secondary industry, and this tendency has caused new college and university graduates to shun secondary industries. I feel that there is an overreaction here.

For a country like Japan lacking in resources and energy, I believe that economic development will be impossible without reinforcing the secondary industries. I wonder what your views are on this point.

Now, about informationalization.

We have no clearcut definition of what an advanced information society is, so there appears to be a trend where each person has his own vision of informationalization. Alvin Toffler caused great repercussions with his theory of "The Third Wave" which in effects states an entirely new culture mode is coming into being in the form of a sophisticated information society.

In a highly advanced information-oriented society, information and software are regarded as inportant sources of management—so much so that information may take over "manpower, products, and money" as the conventional corporate resources.

When a highly advanced society is set up and when new media actually start functioning, this will have greatest impact on our industry and social life.

When new midia have infiltrated into society, the effects that will result are still more guesswork but as far as the pulp and paper industry is concerned, there are two aspects : the utillization of information systems and the supply of paper for this utilization. These two trends deserve close watching.

Last, I would like to touch upon "internationalization."

In the initial stages, overseas investment activity by the Japanese pulp and paper industry was designed to secure material wood resources, followed by the launching of local pulp production in areas with an abundance of low-priced energy and water. These were developmental import-type investments undertaken to acquire prescribed quantities of the products. From this point, producers towards final products in the form of newsprint and printing paper. The investment mode changed to take the form of mergers with local enterprises, capital participation in local businesses, acquisition of existing plants, and further plant construction by individual enterprises. Investment activity widened in scope and the pulp and paper industry ushered in the era of full-fledged internationalization.

Future international strategy, as a matter of course, will vary according to the circumstances surrounding the industry, and the business strategies of individual enterprises. Inevitably there is a limit to discussions of generalized internationalization strategy at the industry level. We must remember that internationalization itself is not the objective, but internationalization has to be achieved to survive and grow in our business. I think we are about to bring in such an era.

Now, I would like to go into the present state and mission of the Japanese pulp and paper industry.

I feel there are important issues here ; Supply and demand, Corporate performance, Cost competitiveness, Raw materials, Energy, Qualitative measures and new product development, Research \& development and Long-term task and outlook.

The first issue is Supply and demand. In 1988, the demand for pulp and paper-particularly paper - has achieved double-digit growth since the first oilcrisis. It has fared especially will during the last several years. Thanks to this encouraging situation, paper companies have been able to achieve very successful results, for which we can all be proud.

Expansion of domestic demand in the Japanese economy, centered around personal consumption and equipment investment is the factor behind the favorable demand situation for paper. In particular, firmness of personal consumption has helped maintain price stability even with the appreciation of the yen in value, the infiltration of a great variety of foreign goods, and renewed efforts by export industries to cultivate domestic demand in the face of the trade friction.

As for changes in demand structure, this is caused by the increase in service businesses and infor- 
mationalization. This has boosted the demand for printing paper, including newsprint and information paper. This lead to briskness in corporate advertising, which in turn was linked to the expansion in demand for printing and information paper.

Meanwhile, active equipment investment has further spurred industrial activity, resulting in strong shipments of board paper for packing industrial materials. All things considered, it was a good year.

In fiscal 1989 , the demand for paper will grow $6.9 \%$ and for board paper $4.4 \%$, making a total of $5.9 \%$ over the previous year, according to an initial calculation by the Federation of Japan Pulp and Paper Association. We are optimistic about this growth.

Regarding the second issue, Corporate performance, the pulp and paper industry-centered around businesses primarily dealing in printing and information paper- has continued to enjoy above-average results for the manufacturing sector since 1983. This earnings growth was made possible by several factors :

The first factor was an increase in the volume of demand for paper and board paper.

The second and the greatest factor for earnings growth was a reduction of variable costs made possible through a falloff in raw material and fuel costs.

The third factor responsible for the increase in profit was a reduction in financial costs resulting from lower interest rates, repayment of loans and diversification of fund procuremet.

Those are the clear factors that contributed to earnings growth, but from late in 1988 to early this year, chip prices tended to rise. Now, because of the falling yen, we will need to break from the past and implement new measures.

Our third issue is cost competitiveness. The pulp and paper industry deals in an international product in the form of chips, pulp, and paper. Because of this, cost competitiveness and qualitative differentiation are essential to survive amid intensifying international competition and to achieve stable growth.

Factors which determine Japan's cost competitiveness include variable costs. The most inportant of these costs are the exchange rate and raw materials (chips, heavy oil); fixed costs in which productivity, and personnel expenses assume great weight; and distribution costs. We should work to control these factors and maintain our competitiveness.

The fourth issue is Maintenance of raw materials. I believe it important that raw materials are maintained under conditions not overly disadvantageous compared with competitive overseas makers so that the Japanese pulp and paper industry can survive amid international competition to achieve stable growth.

The volume of consumption of pulp materials registered a high growth rate 7 percent in 1988, resulting from an increase in pulp production. Meeting this sharp rise in consumption, the supply of domestic materials increased only 2 percent, while imported materials surged 17 percent. In fact, this was an all-time high for industry in terms of the volume of imported materials and the ratio of reliance on imported materials.

A distinctive feature of imported materials recently caused by the strong yen is a change in procurement areas with the launching of imports from distant locations such as Chile in South America, which takes more than one month for transportation, and from U.S. southern states, which takes twice as much time as shipments from the U.S. west coast. Another important factor in the future maintenance of material wood and chips is the stable supply of domestic chips. To maintain a steady supply of home-made chips, we must secure young workers and improve labor productivity in the production of legs and chips through mechanization.

Now, regarding waste paper. Waste paper now accounts for as much as half of paper materials, and given the Global environmental problem and the urban waste problem, I think we need to work on recycling.

Old newspapers and magazines and used corrugated cardboard have reached high levels in recovery and utilization ratios. I think that in coming years importance will be attached to other fields through the sorting and recovery of white waste paper and waste paper from offices, and exploring the possibility of using these 
as paper materials. At present about, 1,200,000 tons of information paper is consumed. Of this, if copier paper and computer print out paper alone are combined, that comes to about 500,000 tons. So if recovery is made even to some extent in this field alone, that should significantly ease the supply of raw materials.

In the above, I have described the supply of raw materials. As I have pointed out, there are many problems involved. And that is the very reason I feel the need to review product standards so that highlyyield pulp and DIP can be used for fine paper.

Now, I will move on to the fifth item, namely "Energy."

Japan is short of energy resources as with wood resources. Stringent energy conversation and investments for rationalization are needed in the pulp and paper industry, whcih consumes energy in great quantities.

The cost ratio of energy in paper and board paper production had steadily declined after peaking at slightly less than 20 percent of total costs in 1980 . In 1988, it declined to less than 10 percent.

Factors contributing to energy's decreasing cost ratio are lower energy unit costs due to the stronger yen, lower oil prices, licreased ratio of independent power generation, increasing switchover to coal, the effects of energy conservation, and greater use of waste paper.

In 1988, however, the basic unit price of purchased energy remained at a standstill for the first time since 1976. Since the beginning of this year, oil prices have strengthened and the recent decline in the yen's value has caused an increase in the unti energy price. Under these circumstances, greater efforts will be required to achieve further energy conservation.

Let's now look at the sixth issue : Qualitative measures and new product development. For the pulp and paper industry of Japan, which is lacking in resources and energy, and where rigid pollution regulations are in force, I believe differentiation in the form of "qualitative measures and new product development" is an essential condition for enduring the highly-cost-competitive international market. This is the best way we can survive and achieve stable growth.

In Japan, for all products, users' qualitative demands are so rigid that these have led to the emergence of outstanding-quality products. These in turn have had a successful reception in world markets. As you know, this has been instrumental in Japan's favorable export results, and is the greatest reason for foreign products' inability to sell in the Japanese marketplace.

Given that user needs for various kinds of paper are becoming increasing divers and sophisticated, it is vitally important that we accurately grasp users needs and meet them as well as possible. A look at recent we trends indicates that in addition of newspapers and magazines, color is becoming popular in the area of copying machines. In terms of orders, trends are moving towards the small-lot, variety formula.

In the case of paper there appears to be no change in outer appearance but in many cases great improvements have been made in the contents. As such, it may not be appropriate to refer to these as new products, and in this respect, new products are hard to come by in the field of paper. Nevertheless, even in this field new porduct development is getting under way, with the accent on specialization, finer quality, and new features. These are called special and functional papers. Our basic technologies comprise sheeting, impregnation, coating, and lamination. By combining these with optimum raw materials, we wish to accelerate new product development, thereby helping the industry achieve stable growth.

The seventh item I would like to touch upon is research \& development.

The scale of research and development in Japan's pulp and paper industry (in terms of researchers and cost) is on par with that in the major countries producting pulp and paper, but it is smaller when compared with other industries.

I am glad that all companies are stepping up their efforts in research and development, and I would like to further improve our company to the maximum extent economically permissible.

I myself spent many years in the research institute, and I feel that what is expected of research institutes and engineers has changed in with the times in post-war Japan.

Japan's technology, which started out with technological ideas from abroad, has climbed to the world's 
top level, and Japan will have to establish its own technology from now on. Originality is indispensable to research and development, and I would like to see improvements in volume as well as quality.

Regarding the last lssue, Long-term task and outlook, I have often heard expressions such as "Challenging the 21st Centry," and "Medium- and long-range vision and business strategy toward the 21st century." I feel that these are healthy signs of enthusiasm about strengthening the foundations of our companies and the industry with the 21st century close at hand.

The Paper-Pulp Technology Forecast Committee disclosed in April of this year the results of a survey entitled, "Paper and pulp in the year $2010 \cdots \cdots$ pulp and paper strategy for the 21 st century," conducted in the areas of demand, raw materials, products and technology. Its contents are full of stimulating suggestions for the prospects for 20 years from now.

Within the industry, the "Study meeting on long-term tasks for the paper-pulp industry" started in September of this year as an advisory organ to the chief of the Consumer Goods Industries Bureau of the Ministry of International Trade and Industry. The working groups of the market \& planning section and raw materials section established under the study meeting will investigate the problem for about a year, and we are looking forward to the outcome. We, too, would like to make further efforts toward that end, work out a comprehensive strategy for the 21st century from a long-term point of view, and strengthen our foundation for another great leap forward.

So far, I have stated just a few of the things we have to think about today. As I said before, our paperpulp industry is faced with quite a few problems. It's up to us engineers to solve them.

For that purpose, I feel that we must acquire an accurate grasp of our present tasks and the outlook for the future. All of you present should exert every effort to solve the difficult problems of the industry, and all the employees of each firm should do what they can to solve the problems facing their companies with ingenuity and new approaches. "A journey of a thousand miles starts with the first step." In taking that first step, I hope you will pursue technological improvement by taking advantage of these events held by JAPAN TAPPI. The association, in turn, will do everything within its power to be of help to you through its various events.

Seeing so many people gathered here today, I have come to recognize anew the importance of the association's role.

In closing, let me express my deepest thanks to everyone who worked to prepare for this meeting, and people from Oji Paper Co.'s Tomakomai Plant who are helping us out in many ways, including plant tours, during this annual meeting.

Thank you 